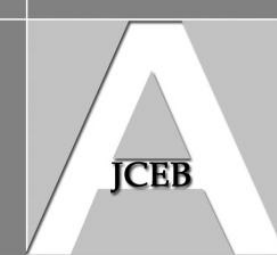

\title{
Boosting Project Outcomes through Goal Alignment: A Case Study of Vietnam
}

Florence Yean Yng Ling and Mai Bich Tram Hien, (National University of Singapore, Singapore)

\begin{abstract}
Goal alignment among members of a project team is important so that individual team members can work towards common project outcomes. This study aims to identify effective goal alignment practices to improve construction project outcomes in Vietnam. With the aid of a survey questionnaire, 31 sets of data were collected from practitioners in Vietnam's construction industry. The overall results show that although there is significant schedule overrun, projects in Vietnam are generally completed within budget. These projects also have significantly good quality and client satisfaction. It was found that schedule performance may improve if buyers and sellers have high degree of alignment in project objectives, and have shared goals that are adjustable. The finding shows project quality may improve if sellers communicate problems relating to quality to buyers, and there is proper documentation of project objectives. Effective communication of problems pertaining to delivery and quality may lead to better client satisfaction. It is recommended that project team members share, align and adjust their goals and objectives in order to achieve a better schedule outcome. It is also recommended that consultants and contractors make adjustments and customize their products to derive higher quality and client satisfaction. Clients should also be fair in sharing project benefits and assessing claims.
\end{abstract}

Keywords: Vietnam, Goal alignment, Project outcomes, Project management

\section{Introduction}

The construction industry faces many problems, such as cost and schedule overrun (Kaliba et al., 2009), lack of cooperation (Chan et al., 2004), and limited trust (Pinto et al., 2009). These issues can lead to adversarial relationships (Chan et al., 2004) and ultimately, affect the project success.

In a construction project, it is natural that different team members strive to achieve their own objectives. There is a constant struggle between "mutual interests" and "individual interests" of the different parties. Based on these two types of interests, inter-organizational relationships could be cooperative, competitive, regulating or conflictive (Van de Ven et. al, 1999). Thompson and Sanders (1998) stated that the traditional owner-contractor relationship is mainly competitive in nature which leads to a low degree of objective alignment.

Project management in Vietnam has been investigated in the following ways: identification of the construction industry's strengths, weaknesses, opportunities and threats (Dapice, 2003); detection of problems faced in large construction projects (Nguyen et al., 2004); evaluation of construction firms' performance using a balanced scorecard and SWOT matrix framework (Luu et al., 2008); case studies of projects with satisfactory and unsatisfactory outcomes (Ling and Bui, 2010); evaluation of project management practices that are associated with poor project outcomes (Ling and Tran, 2012a); association between trust, competency, communication and relational transactions (Ling and Tran, 2012b); and correlation between relational contracting practices and interpersonal relationships (Ling and Tran, 2012c).

While goal alignment has been studied in some countries (e.g. Stephen and Coote, 2007), 
hitherto, it is not known what strategies are adopted for goal alignment among team members in Vietnam. Strategies adopted to enhance goal alignment have not yet been explored in depth in the Vietnamese context, and the association between goal alignment strategies and project outcomes is not known. This research aims to fill the gap by investigating the effect of goal alignment on project outcomes in Vietnam. The specific objectives are to investigate the extent to which practices relating to goal alignment are adopted in Vietnam, and the association between these practices and project outcomes. Project outcomes are operationalized into the usual cost growth, schedule growth, project quality, and client satisfaction. Goal alignment practices are those which align team members with the project objectives.

This research focuses on construction projects undertaken in Vietnam. Both public and private projects from different provinces in Vietnam are explored. Vietnam is worth studying because it is one of the most dynamic countries in South East Asia (World Bank, 2012), with her construction industry contributing 41.1 per cent to the Gross Domestic Product (GDP) (Global Finance, 2012).

\section{Overview of Vietnam's Construction Industry}

From a poor country faced with numerous problems such as hyperinflation and famine, Vietnam has transformed into a developing country whose economy has flourished rapidly. According to the World Bank (2012), Vietnam's economy has grown at an annual rate of 7.3 per cent between 1990 and 2010, and for the next decade, the aim is to achieve a 10 per cent annual growth rate so as to attain a per capita income of US $\$ 3000$. Vietnam's progress can be attributed to foreign investment, reduction in poverty, high flow of international trade, health care, and the development of infrastructures (World Bank, 2012).

The construction industry in Vietnam is experiencing high growth despite the global financial turmoil in recent times (Business Monitor International, 2012). The General Statistics Office of Vietnam highlighted that in 2011, the construction sector in Vietnam reached USD 32.2 billion, an escalation of 18.4 per cent compared to 2010. There is a construction boom in various areas such as infrastructures, hotels, offices, and residential and industrial buildings (Nation Encyclopedia, 2012).

Although the construction boom is viewed with much optimism, the industry still faces many problems that prevent it from achieving successful outcomes. The mean cost performance

is 2.95 on a 7 -point scale ( $1=$ overrun budget by $>5$ per cent ; $4=$ final cost same as budget; and $7=$ below budget by $>5$ per cent ), and this is significantly poor (Ling and Tran, 2012a). Schedule performance is also significantly poor, at a mean of 2.21 on a 7-point scale $(1=$ late finish by $>5$ per cent ; 4 = finish on time; 7 = early finish by $>5$ per cent ) (Ling and Tran, 2012a). Hoai et al. (2008) identified the five main causes of construction cost and schedule overrun in Vietnam as: poor site management and supervision; poor project management; owners' financial difficulties; contractors' financial difficulties; and frequent changes in design. Other reasons for poor performance are bad traffic situation and the lack of accurate data on soil and weather conditions (Ling and Bui, 2010).

\section{Framework and Hypotheses}

The framework for this study is that goal alignment among buyers and sellers leads to better project outcomes. In the sections below, project outcomes and goal alignment are defined and operationalized.

\section{Performance Outcome Measurement}

Traditionally, a project is considered successful if it is delivered on time, within budget, and of accepted quality (PMI, 2004). Konchar and Sanvido (1998) measured success in terms of unit cost, construction speed, delivery speed, cost growth, schedule growth and several 
quality measures. Chan and Chan (2000) produced a consolidated framework which included the additional dimensions of user expectation, participant's satisfaction, environmental performance, health and safety, and commercial value. To this list, Ling et al. (2004) added owner's satisfaction and owner's administrative burden. If the final cost or schedule exceeds what is planned, buyers' satisfaction would be compromised (Kaliba et al., 2009). Bubshait and Almohawis (1994) found quality performance a significant contributor to the existence of satisfaction in a project. Kim et al. (2012) discovered that quality is an important factor in time-cost trade-off problems, that is, the achieved overall quality of a project should be maximized within a given time frame and budget. From these studies, this research chose four performance measures to ascertain project outcomes on the basis of minimizing overlaps among the performance measures. These were used as the dependent variables of this study. Project outcome is operationalized into: cost growth (Y1), schedule growth (Y2), project quality (Y3), and client satisfaction (Y4).

\section{Goal Alignment}

Goal alignment is defined as buyers and sellers: having very similar project-related goals and attitudes towards what needed to be achieved; having compatible project-related goals, supporting each other's objectives; having agreement upon project-related goals (Jap, 1999; Stephen and Coote, 2007). Goal alignment has been found to help team members attain the best values (Walker et al., 2002) and enable contractors to achieve better financial performance (Stephen and Coote, 2007). Child (1984) found a high and positive correlation between goal alignment among members in the project and project outcomes. For goal alignment to occur, team members should exhibit relational behaviour (Stephen and Coote, 2007), and have joint action (Wright et al., 2001). They should avoid maximizing self-interest or having incongruent goals (Eisenhardt, 1989). When parties have goal alignment, they are integrated as there is unity of effort between various subsystems with coordinated solidarity in the accomplishment of common organizational goals (Lansley et. al, 1974). Based on the literature review, goal alignment practices are categorized into the following: shared/common objectives; communication; flexibility; and fairness.

\section{Shared/common objectives}

Goal alignment may be achieved through shared objectives, which leads to the development of successful relationships (Thompson and Sanders, 1998). Clear mutual objectives that can meet the aims of both parties help them put effort in the same direction (Thomas and Thomas, 2005). In addition, common objectives provide a win-win situation because it creates an idea that if people cooperate towards the same direction, they can produce more than enough of what they want (Chartered Institute of Building, 2010). Swan and Khalfan (2007) suggested a partnering workshop in order to obtain shared objectives between parties and that it takes place at the beginning of a project. Although there is an initial cost and time involved, mutual objectives are likely to prevent resource and time wastage at later stages (Chartered Institute of Building, 2010). From the literature review, the following goal alignment strategies are identified: buyers and sellers have shared goals (X1); buyers and sellers' project objectives are aligned (X2); buyers and sellers business/commercial objectives are aligned (X3); and project goals are adjusted to take care of everyone's interests when conflicts happen (X4).

\section{Communication}

In a project-based industry, the interaction between unfamiliar groups of people coming together for a short period of time is problematic and unproductive (Dainty et al., 2006). To align goals, project team members need to communicate openly, directly and in a timely manner (Larson, 1995; Hellard, 1996) so that problems can be solved immediately in the early stages (Dunston and Reed, 2000). Goal alignment takes place when parties are allowed to review and give feedback (Kawneer, 2001). In addition, effective communication can facilitate the setting of visions, idea exchanges as well as problem solving (Cheng et al., 2000). Goal alignment strategies are operationalized as: sharing of information between

Ling, F Y Y and Hien, M B T (2014) 'Boosting project outcomes through goal alignment: a case study of Vietnam', Australasian Journal of Construction Economics and Building, 14 (2) 73-86 
buyers and sellers (X5); sellers communicating with buyers on problems relating to timely delivery (X6) and quality (X7); sellers' method of communicating to reduce organizational and interpersonal clashes (X8); and buyers' method of communicating to reduce uncertainties about the project (X9).

\section{Flexibility}

Goal alignment ensures that when the project faces an unexpected situation, parties face less uncertainty about the proper course of action and can react appropriately (Sorensen, 2002). As each party has its own objectives prior to alignment, some form of customization is needed for goal alignment. Chan et al. (2011) recommended that conflicting individuals look for a common satisfactory solution by adopting joint problem solving and seeking alternatives. Goal alignment strategies relating to flexibility are operationalised as a seller's willingness to meet the buyer's needs by: making adjustments to its products/services $(X 10)$, customizing its products/services (X11), and being flexible when changes are required (X12).

\section{Fairness}

Goal alignment should ensure that the rights and interests of different parties are also taken care of. This is usually achieved by contracts which include clear terms of responsibility and fair risk allocation (Zaghloul and Hartman, 2003). Solutions to problems should be based on equality and mutual goals (Vaaland, 2004). Strategies for goal alignment are operationalized as: sharing project benefits fairly (X13); being fair in evaluating claims (X14); and having a written agreement of objectives of different parties (X15).

\section{Research Hypothesis}

From the literature review, it is hypothesized that:

$\mathrm{H}$ : An increase in the adoption of goal alignment practices leads to an improvement in project outcomes.

\section{Research Method}

A survey was conducted to investigate goal alignment practices that are significantly associated with project outcomes. A draft survey questionnaire was drawn up based upon the goal alignment related literature, and the literature review on project outcomes. Four project outcomes (Y1 to $\mathrm{Y} 4)$ and 15 goal alignment practices (X1 - X15) that may be adopted in construction projects were identified from the literature.

After translating the questionnaire into Vietnamese, it was presented to three construction professionals (experts) in Vietnam for testing. The experts were asked to identify any ambiguous questions and wordings. Based on feedback from the pilot study, the questionnaire was revised, refined and ambiguities removed to ensure that it was appropriate in the Vietnamese context and sent back to these professionals for re-evaluation. The questionnaire was then finalized, and an industry wide survey was conducted.

The questionnaire was divided into 3 sections. Section A requested information of a particular completed construction project of respondents' choice that they had been involved with in Vietnam. However, projects must be recently completed (after 2000) so that the data would not be outdated. The respondents' firms must have been involved in these projects as project owners, consultants or contractors. Section A provided definitions of buyers and sellers, and respondents were asked to indicate what buyer role they played, and which seller they were basing their response on. Actual and planned cost and schedule information was solicited to calculate $Y 1$ and $Y 2$. Respondents were also asked to rate project quality (Y3) and client satisfaction (Y4) on an anchored 5-point Likert scale ( 1 = very low; 5 = very high). In Section B, respondents were asked to indicate the extent to which goal alignment practices (X1 - X15) were adopted in the project on a similar 5-point Likert scale. The last section gathered demographic characteristics of the respondents and their companies. 
The population in this study comprised "buyers" in Vietnam's construction industry, defined as those who need to procure products or services for construction projects. These buyers are: clients who buy consultancy and construction services from consultants and contractors respectively; consultants who receive construction services of contractors; and contractors who buy services and products from subcontractors and suppliers. The sampling frame consisted of "buyers" defined above, working in Ho Chi Minh City (HCMC). Random sampling was adopted for the selection of samples. To increase the number of respondents, convenience sampling and snowball sampling were also adopted.

The self-administered questionnaire was first sent to the subjects by email. E-mail was chosen because it could efficiently reach a large sample, and allowed ease of response. Subjects were told that they may return the completed questionnaire by email or request for researchers to interview them to help them to complete the questionnaire.

\section{Data Analysis}

After the questionnaires were received, they were checked and coded. Cost growth (Y1) and schedule growth (Y2) were calculated as follows:

- Cost growth $(\mathrm{Y} 1)=($ Final cost - Original cost $) /$ Original cost $X 100$ per cent

- Schedule growth $(\mathrm{Y} 2)=$ (Final duration - Planned duration $) /$ Planned duration) $X 100$ per cent .

In addition, $\mathrm{Y} 1$ and $\mathrm{Y} 2$ which were given in percentages were coded into a 5-point scale, as Y1' and Y2' (see Table 1) to allow all the variables to be measured on the same scale.

The one-sample $t$-test was performed using the Statistical Package for Social Sciences (SPSS) software on the four performance metrics to determine if the projects had significantly good outcomes ( $Y 1$ to $Y 4$ ). For each $Y$ variable, the null hypothesis is that the outcome is neutral, and the alternative hypothesis that the outcome is significantly good ( $t$ value positive, $p<0.05$ ) or significantly poor (t value negative, $p<0.05$ ). The null hypothesis $\mathrm{H}_{0}: \mu=\mu_{0}$ was tested against the alternative hypothesis $\mathrm{H}_{1}: \mu \neq \mu_{0}$, here $\mu$ was the population mean. $\mu_{o}$ is the hypothetical mean above/below which the outcome is considered significantly good/poor. $\mu_{\mathrm{o}}$ for $\mathrm{Y} 1$ and $\mathrm{Y} 2$ were set at 0 because this represents 0 per cent cost growth or schedule growth. $\mu_{0}$ for $Y 1^{\prime}, Y^{\prime}, Y 3$ and $Y 4$ was set at 3 because by definition given in the 5-point rating scale, 3 is anchored as no growth ( $\mathrm{Y} 1^{\prime}$ and $\mathrm{Y} 2$ ') and meeting expectations ( $\mathrm{Y} 3$ and $\mathrm{Y} 4$ ).

T-test was also used to find out if the goal alignment practices $(X 1-X 15)$ were adopted to a significant extent. The null hypothesis $\mathrm{H}_{0}: \mu \leq \mu_{0}$ was tested against the alternative hypothesis $\mathrm{H}_{1}: \mu>\mu_{0}$, here $\mu$ was the population mean. $\mu_{0}$ is the hypothetical mean above which the practice is considered to have been adopted to a significant extent. $\mu_{\circ}$ was set at 3 because by definition given in the 5-point rating scale, 3 is anchored as neutral. When $p<$ 0.05 and the $t$ value is positive, it is concluded that the practice was adopted to a significant extent.

In order to check the influence of a goal alignment practice $(X 1-X 15)$ on project outcome (Y1 - Y4), Spearman's correlation analysis was conducted. A goal alignment practice is considered significantly correlated with a performance outcome when $p<0.05$.

\section{Characteristics of the Sample}

Ninety sets of questionnaires were sent out, and 31 responses were received. The response rate of 34 per cent is within the expected range of 20-40 per cent for surveys of this nature. Inferential statistical analysis could be carried out because in accordance with the generally accepted rule, the central limit theorem holds true when the sample size is $\geq 30$ (Ott and Longnecker, 2001).

Ling, F Y Y and Hien, M B T (2014) 'Boosting project outcomes through goal alignment: a case study of Vietnam', Australasian Journal of Construction Economics and Building, 14 (2) 73-86 


\begin{tabular}{|c|c|c|}
\hline Characteristics & Frequency & per cent \\
\hline \multicolumn{3}{|l|}{ Designation } \\
\hline Upper management & 6 & 19.4 \\
\hline Middle management & 12 & 38.7 \\
\hline Professionals & 13 & 41.9 \\
\hline \multicolumn{3}{|l|}{ Experience in industry (years) } \\
\hline Less than 10 & 16 & 51.6 \\
\hline $10-20$ & 13 & 41.9 \\
\hline Above 20 & 2 & 6.5 \\
\hline \multicolumn{3}{|l|}{ Respondents' roles in the projects } \\
\hline Operation & 3 & 9.7 \\
\hline Control & 15 & 48.4 \\
\hline Management & 13 & 41.9 \\
\hline \multicolumn{3}{|l|}{ Respondents' firm type } \\
\hline Government sector clients & 3 & 9.7 \\
\hline Private clients/developers & 5 & 16.1 \\
\hline Main contractors & 16 & 51.6 \\
\hline Consultants & 7 & 22.6 \\
\hline \multicolumn{3}{|l|}{ Project type } \\
\hline Residential & 12 & 38.7 \\
\hline Office & 9 & 29.0 \\
\hline Hotel & 3 & 9.7 \\
\hline Industrial & 5 & 16.1 \\
\hline Others & 2 & 6.5 \\
\hline \multicolumn{3}{|l|}{ Location of the projects } \\
\hline Ho Chi Minh City & 20 & 64.5 \\
\hline Nearby provinces of Ho Chi Minh City & 6 & 19.4 \\
\hline Other parts of Vietnam & 5 & 16.1 \\
\hline \multicolumn{3}{|l|}{ Nature of the projects } \\
\hline Government sector & 3 & 9.7 \\
\hline Private sector & 28 & 90.3 \\
\hline \multicolumn{3}{|l|}{ Size of project $\left(\mathrm{m}^{2}\right)$} \\
\hline Not exceeding $1,000 \mathrm{~m}^{2}$ & 8 & 25.8 \\
\hline $1,000 m^{2}-10,000 m^{2}$ & 11 & 35.5 \\
\hline $10,001 m^{2}-50,000 m^{2}$ & 8 & 25.8 \\
\hline $50,001 m^{2}-100,000 m^{2}$ & 4 & 12.9 \\
\hline \multicolumn{3}{|l|}{ Respondent-firms' role in project } \\
\hline Client's representative & 6 & 19.4 \\
\hline Consultants & 8 & 25.8 \\
\hline Main contractor & 17 & 54.8 \\
\hline \multicolumn{3}{|l|}{ Cost growth (Y1) (5-point scale) } \\
\hline Point $1: \leq-5$ per cent & 5 & 16.1 \\
\hline-5 per cent $<$ Point $2<0$ per cent & 2 & 6.5 \\
\hline Point 3: 0 per cent & 9 & 29.0 \\
\hline 0 per cent $<$ Point $4 \leq 5$ per cent & 11 & 35.5 \\
\hline Point $5>5$ per cent & 4 & 12.9 \\
\hline \multicolumn{3}{|l|}{ Schedule growth (Y2) (5-point scale) } \\
\hline Point $1: \leq-5$ per cent & 0 & 0 \\
\hline-5 per cent $<$ Point $2<0$ per cent & 4 & 13.3 \\
\hline Point 3: 0 per cent & 14 & 46.7 \\
\hline 0 per cent $<$ Point $4 \leq 5$ per cent & 7 & 23.3 \\
\hline Point $5>5$ per cent & 5 & 16.7 \\
\hline
\end{tabular}

Table 1 Characteristics of respondents, their firms, and projects

Note: $\mathrm{n} \neq 31$ because some respondents did not provide the information.

Ling, F Y Y and Hien, M B T (2014) 'Boosting project outcomes through goal alignment: a case study of Vietnam', Australasian Journal of Construction Economics and Building, 14 (2) 73-86 
The characteristics of the respondents are shown in Table 1. The majority of respondents are from the middle management and professional categories. The average working experience of respondents is 10.19 years, and their involvement in the construction industry in Vietnam ranges from five years to 30 years. Most of the respondents played a control or management role in their projects.

Table 1 also shows the characteristics of the projects that respondents reported on. The majority are building projects located in $\mathrm{HCMC}$ and southern Vietnam, and they belong to the private sector. The size of the reported projects varies from $60 \mathrm{~m}^{2}$ to $100,000 \mathrm{~m}^{2}$ with the average of $14,850 \mathrm{~m}^{2}$.

\section{Results}

Table 2 shows the project outcomes (Y1 to $\mathrm{Y} 4)$. The mean cost growth is 1.15 per cent (Y1) or 3.23 on a 5 -point scale ( $\left(1^{\prime}\right)$. The $t$-test shows that there is no significant cost overrun (Table 2). The mean schedule performance (Y2) is 8.98 per cent or 3.43 based on a 5 -point scale (Y2'). The $t$-test results show that there is significant schedule overrun in the projects. Table 2 also shows that project quality (Y3: mean $=3.61)$ and client satisfaction (Y4: means $=3.42$ ) are significantly high. It can be concluded that the respondents have reported projects that were completed within budget, had high quality and client satisfaction, but they were significantly delayed.

\begin{tabular}{|c|l|c|c|c|}
\hline Code & \multicolumn{1}{|c|}{ Performance matrix } & Mean & T value & Sig. (2-tail) \\
\hline Y1 & Cost growth (percentage) & 1.15 & 1.007 & 0.161 \\
\hline Y1' & Cost growth (5-point scale) & 3.23 & 1.000 & 0.163 \\
\hline Y2 & Schedule growth (percentage) & 8.98 & 2.315 & $0.014^{*}$ \\
\hline Y2' & Schedule growth (5-point scale) & 3.43 & 2.538 & $0.017^{*}$ \\
\hline Y3 & Project quality (5-point scale) & 3.61 & 4.770 & $0.000^{* *}$ \\
\hline Y4 & Client satisfaction (5-point scale) & 3.42 & 4.139 & $0.000^{\star *}$ \\
\hline
\end{tabular}

Table 2 Project outcomes

${ }^{*} p<0.05 ;{ }^{* *} p<0.01$

Among the 15 practices relating to goal alignment, Table 3's $t$-test results show that 12 are adopted to a significant extent, while X4, X5, and X15 are not. The correlation test does not show significant correlation between $\mathrm{Y} 1$ (cost performance) and any of the goal alignment practices. This suggests that cost performance is not dependent on goal alignment among the project team members, but other factors such as control and scope management.

The correlation results in Table 3 show that five goal alignment practices $(X 1, X 2, X 4, X 5$, and $\mathrm{X} 13$ ) are significantly correlated with schedule performance (Y2'). Quality (Y3) and client satisfaction (Y4) are significantly correlated with four and five goal alignment practices, respectively.

\section{Discussion}

This section discusses the statistical results in Table 3.

\section{Shared Objectives among Team Members}

The results in Table 3 show that three practices relating to sharing goals and objectives are significantly and negatively correlated with schedule growth (Y2'): sharing of goals and objectives between buyers and sellers ( $X 1$ : $r=-0.446, p=0.014)$; alignment of project objectives among different parties (X2: $r=-0.386, p=0.035)$; and adjusting goals to ensure everyone's interests when conflicts happen ( $X 4: r=-0.373, p=0.043)$.

Shared goals and aligned objectives are important because they can promote a better

Ling, F Y Y and Hien, M B T (2014) 'Boosting project outcomes through goal alignment: a case study of Vietnam', Australasian Journal of Construction Economics and Building, 14 (2) 73-86 
working environment (Ali et al., 2010) and help parties work towards the same direction. As a result, much time can be saved which leads to the reduction of schedule growth. These collaborative atmospheres can therefore assist parties achieve project success (Black et al., 2000).

The finding that adjusting goals to ensure everyone's interests when conflicts happen $(X 4)$ is significantly correlated with Y2' confirms Verma's (1998) study which showed that goal adjustments that are made to ensure everyone's interests when conflicts happen strongly affect time performance. The t-test result shows that this is not adopted often enough, probably because when conflicts happen, each party wants to safeguard its own interest, and ultimately project schedule may be compromised.

\begin{tabular}{|c|c|c|c|c|c|c|c|}
\hline Code & Factors & Mean & $\begin{array}{l}\text { T value } \\
\text { (1-tail } \\
\text { sig) }\end{array}$ & Y2' & Y3 & Y4 & Total \\
\hline & Shared/common objectives & & & & & & \\
\hline $\mathrm{X} 1$ & $\begin{array}{l}\text { Extent to which buyers and sellers have shared } \\
\text { goals }\end{array}$ & 3.42 & $\begin{array}{l}3.474 \\
.001^{* *}\end{array}$ & $\begin{array}{l}-.446^{*} \\
.014\end{array}$ & & & 1 \\
\hline $\mathrm{X} 2$ & $\begin{array}{l}\text { Level of alignment of project objectives of } \\
\text { different parties }\end{array}$ & 3.39 & $\begin{array}{l}2.834 \\
.004^{* *}\end{array}$ & $\begin{array}{l}-.386^{*} \\
.035\end{array}$ & & & 1 \\
\hline X3 & $\begin{array}{l}\text { Level of alignment of business/commercial } \\
\text { objectives of different parties }\end{array}$ & 3.42 & $\begin{array}{l}2.892 \\
.004^{* *}\end{array}$ & & & & 0 \\
\hline \multirow[t]{2}{*}{$\mathrm{X} 4$} & $\begin{array}{l}\text { Extent to which goals are adjusted to take care of } \\
\text { everyone's interests when conflicts happen }\end{array}$ & 3.16 & $\begin{array}{l}1.000 \\
.163\end{array}$ & $\begin{array}{l}-.373^{*} \\
.043\end{array}$ & & & 1 \\
\hline & Communication & & & & & & \\
\hline $\mathrm{X} 5$ & $\begin{array}{l}\text { Effectiveness of information sharing between } \\
\text { buyers and sellers }\end{array}$ & 3.23 & $\begin{array}{l}1.366 \\
.091\end{array}$ & $\begin{array}{l}-.361^{*} \\
.050\end{array}$ & & & 1 \\
\hline $\mathrm{X} 6$ & $\begin{array}{l}\text { Effectiveness of sellers' method of } \\
\text { communicating its delivery problems with buyers }\end{array}$ & 3.42 & $\begin{array}{l}3.243 \\
.002^{* *}\end{array}$ & & & $\begin{array}{l}.406^{*} \\
.024\end{array}$ & 1 \\
\hline $\mathrm{X} 7$ & $\begin{array}{l}\text { Effectiveness of sellers' method of } \\
\text { communicating its quality problems with buyers }\end{array}$ & 3.45 & $\begin{array}{l}3.105 \\
.002^{* *}\end{array}$ & & $\begin{array}{l}.494^{* \star} \\
.005\end{array}$ & $\begin{array}{l}.476^{* *} \\
.007\end{array}$ & 2 \\
\hline $\mathrm{X} 8$ & $\begin{array}{l}\text { Effectiveness of sellers' method of } \\
\text { communicating to reduce organizational and } \\
\text { interpersonal clashes }\end{array}$ & 3.61 & $\begin{array}{l}3.450 \\
.001^{* *}\end{array}$ & & $\begin{array}{l}.635^{* *} \\
.000\end{array}$ & & 1 \\
\hline \multirow[t]{2}{*}{ X9 } & $\begin{array}{l}\text { Effectiveness of buyers' method of } \\
\text { communicating to reduce uncertainties about the } \\
\text { project with sellers. }\end{array}$ & 3.48 & $\begin{array}{l}2.802 \\
.005^{\star *}\end{array}$ & & & & 0 \\
\hline & Flexibility & & & & & & \\
\hline $\mathrm{X} 10$ & $\begin{array}{l}\text { Extent to which sellers made adjustments to their } \\
\text { products/ services to meet buyers' needs }\end{array}$ & 3.48 & $\begin{array}{l}2.402 \\
.012^{*}\end{array}$ & & $\begin{array}{l}.502^{* \star} \\
.004\end{array}$ & & 1 \\
\hline $\mathrm{X} 11$ & $\begin{array}{l}\text { Extent to which sellers customized their products/ } \\
\text { services to meet buyers' needs }\end{array}$ & 3.58 & $\begin{array}{l}3.258 \\
.002^{* *}\end{array}$ & & & $\begin{array}{l}.456^{* \star} \\
.010\end{array}$ & 1 \\
\hline \multirow[t]{2}{*}{$\mathrm{X} 12$} & $\begin{array}{l}\text { Extent to which sellers showed flexibility when } \\
\text { changes were required }\end{array}$ & 3.39 & $\begin{array}{l}3.503 \\
.001^{* *}\end{array}$ & & & & 0 \\
\hline & Fairness & & & & & & \\
\hline $\mathrm{X} 13$ & $\begin{array}{l}\text { Level of fairness in sharing project benefits } \\
\text { between buyers and sellers }\end{array}$ & 3.52 & $\begin{array}{l}4.593 \\
.000^{* *}\end{array}$ & $\begin{array}{l}-.423^{*} \\
.020\end{array}$ & & & 1 \\
\hline $\mathrm{X} 14$ & $\begin{array}{l}\text { Level of fairness when buyers evaluated claims } \\
\text { submitted by sellers }\end{array}$ & 3.26 & $\begin{array}{l}2.108 \\
.022^{*}\end{array}$ & & & $\begin{array}{l}.505^{* *} \\
.004\end{array}$ & 1 \\
\hline \multirow[t]{2}{*}{$\mathrm{X} 15$} & $\begin{array}{l}\text { Extent to which objectives of different parties are } \\
\text { formally documented in writing }\end{array}$ & 3.10 & $\begin{array}{l}.722 \\
.238\end{array}$ & & $.450^{*}$ & $\begin{array}{l}.415^{*} \\
.020\end{array}$ & 2 \\
\hline & Total & & & 5 & 4 & 5 & \\
\hline
\end{tabular}

Table 3 Summary of statistical results

Notes: Only significant correlations are shown. Within each cell, the top and bottom figures are the correlation coefficient and sig. level, respectively. ${ }^{*}$ Correlation is significant at the 0.05 level (2-tailed). ${ }^{* *}$ Correlation is significant at the 0.01 level (2-tailed). Y1 is not significantly correlated with any of the factors.

Ling, F Y Y and Hien, M B T (2014) 'Boosting project outcomes through goal alignment: a case study of Vietnam', Australasian Journal of Construction Economics and Building, 14 (2) 73-86 


\section{Communication among Team Members}

Table 3 shows that communication practices are significantly correlated with $Y 2$ ', $Y 3$, and $Y 4$, indicating the importance of communication in goal alignment. There is a significant negative correlation between schedule growth and sharing of information between sellers and buyers ( $X 5: \mathrm{r}=-0.361, \mathrm{p}=0.050$ ). This indicates that when more information is shared, the project is likely to be completed on time. The result is consistent with Dainty et al.'s (2006) finding that sharing information throughout a project develops a collaborative environment that can facilitate the project management process and results in a significant reduction of schedule growth. The t-test result shows that sharing of information is not done often enough. This indicates that there is a lack of effective information sharing, and parties may not be working collaboratively which would cause time delay (Meng, 2012).

When sellers are able to communicate problems regarding delivery (X6) and quality (X7) more effectively, the correlation results show that the projects also experience higher quality (Y3) and client satisfaction (Y4) (Table 3). This may be because when issues surface, the easy ability of sellers to discuss them openly will help all parties to address the problems collectively and solve them immediately with inputs from various members in their respective capacities. This result supports Dainty et al.'s (2006) finding that poor communication leads to poor quality. One possible reason is that effective communication can motivate people to work effectively towards the same direction and hence produce better quality products. If anyone withholds their information and problems, more major issues are created and this can lead to poor quality (Munns, 1995).

\section{Flexibility displayed}

Table 3 shows that there is a significant correlation between project quality (Y3) and sellers' willingness to make adjustments to meet buyers' needs (X10: $r=0.502, p=0.004)$. There is also a significant correlation between client satisfaction (Y4) and sellers' willingness to customize products to meet buyers' needs $(X 11: r=0.456, p=0.010)$. These findings indicate that sellers' flexibility can lead to better quality and satisfaction. The importance of flexibility is also confirmed by Lim et al. (2011) who found that contractors need to: respond to changes attributed to unpredictable changes in clients' requirements; have flexible work procedure; and have the ability to change current practices. While the questionnaire asked about extent to which sellers were flexible, it should be noted that flexibility should not be one sided to accommodate the requests from buyers only. It is also important for buyers to be flexible, as was the case of a successful hospital development, where clients were prepared to accept alternative proposals by consultants and contractors as long as the function of the facility was not compromised, and this helped to minimize the occurrence of conflicts, and enhanced the relationships between the parties (Ling and Tan, 2014).

\section{Fairness in dealing with each other}

Table 3 shows that all the three goal alignment practices relating to fairness $(X 13, X 14$, and $\mathrm{X} 15)$ are significantly correlated with $\mathrm{Y} 2$ ', $\mathrm{Y} 3$, and $\mathrm{Y} 4$, suggesting the importance of being equitable. There is a significant negative correlation between schedule growth (Y2') and fairness in sharing project benefits (X13: $r=-0.423, p=0.020)$. One possible reason is that fairness, especially in monetary sharing, can be seen as a motivator for members to work harder towards project success. A benefit-sharing agreement can help to promote effective communication and conflict resolution (World Bank, 2009). Because for the benefit of all parties, when issues surface, team members will try to minimize the time taken to resolve them. When organizational justice is perceived, conflict intensity levels are likely to reduce and the tendency to dispute also decreases (Aibunu et al., 2011). These allow team members to execute the project without delay.

Client satisfaction $(\mathrm{Y} 4)$ is significantly correlated with fairness in submitting and valuing claims ( $\mathrm{X} 14$ : $r=0.505, \mathrm{p}=0.004)$. In construction projects, changes happen frequently and 
sellers who submit fair and reasonable claims can save buyers' time in evaluating them, leading to higher satisfaction. Similarly, when buyers assess the variations fairly, sellers are more likely to agree to the value of the variations and proceed with the work with minimum dispute and disruption, thereby increasing client satisfaction. The result confirms Aibinu et al.'s (2008) finding that the procedure for administering claims must be perceived to be fair as this reduces a contractor's uncooperative attitude especially if he is receiving an unfavourable decision.

The result in Table 3 shows that when there is a higher degree of written agreement of project objectives of different parties (X15), project quality (Y3) and client satisfaction (Y4) are also likely to be higher. A written agreement is a permanent record of what is desired of a project and allows parties to consider carefully the terms that they want to include in the agreement (Dainty et al., 2006). This type of agreement promotes understanding between parties and minimizes misinterpretation (Dainty et al., 2006). The t-test result shows that this is not practised to a significant extent. Agreements should be written to ensure consistency, prevent amnesia and allow parties to always refer to what has been written when it comes to ambiguity or disputes (Nolo, 2013).

\section{Limitations of the Research}

Despite much effort to collect more data, only 31 respondents agreed to participate in the study. Thus, the main limitation of this study is the small sample size which limits the scope for generalization of the respondents' perceptions to the overall population. Other Vietnam studies also reported small sample sizes. For example, Ling and Tran's (2012a) study of project management in Vietnam had 38 respondents and Ling and Tran's (2012b) investigation of trust in project teams in Vietnam had 36. The results established from the statistical analyses must be interpreted with care, giving due considerations for potential under-coverage bias and to reliability issue. However, in the absence of other studies from Vietnam, the findings provide some guidance to practitioners on the goal alignment practices that may boost project outcomes. In future, research could be undertaken on a larger sample of practitioners, and using other data collection methods to elicit higher responses.

Another limitation is the subjectivity of the responses since the questionnaire is based on a 5-point Likert scale. Different respondents may assign different points on the Likert scale when rating quality, satisfaction and extent of adoption of goal alignment practices. The responses are also based on respondent-buyers' perception, and may not truly represent the actual situation or what sellers perceived. In addition, findings obtained from this study are mostly limited to private sector projects in Ho Chi Minh City and nearby provinces. The majority of respondents are main contractors, suggesting that the results would be more relevant to goal alignment between contractors and subcontractors/suppliers.

\section{Conclusion}

This study was conducted to find out what are the effective goal alignment related practices that could lead to better project outcomes in Vietnam. Among the 15 goal alignment practices, 12 were adopted to a large extent. It is recommended that adjusting goals to ensure every team member's interests are taken care of when conflicts happen (X4) and sharing information between buyers and sellers (X5) be adopted to a greater extent to reap better schedule performance. In addition, there should be greater adoption of written agreement of objectives of different parties (X15) in order to derive better quality and satisfaction.

The correlation analyses show that 12 goal alignment related practices are significantly correlated with schedule, quality, and client satisfaction (see Table 3). The implication is that these should be adopted to a larger extent. To reduce time over-run, more of the following are recommended between buyers and sellers: sharing, alignment and adjustment of goals

Ling, F Y Y and Hien, M B T (2014) 'Boosting project outcomes through goal alignment: a case study of Vietnam', Australasian Journal of Construction Economics and Building, 14 (2) 73-86 
and objectives, sharing of information, and fair distribution of project benefits. Sharing mutual objectives will ensure that it is in the interests of each party to work towards the overall project success. When parties are assured that their interests are protected, they will desire to maintain the relationships with sellers. Thus, it is recommended that sellers keep in mind that shared objectives with buyers would not only develop the relationships, but also bring project success and benefits to all parties.

To achieve higher project quality, the implication is that sellers should communicate more effectively and make adjustments to meet buyers' needs. During the execution of a project, information sharing and effective communication are encouraged between buyers and sellers so as to update each other on project progress and any difficulties that contractors may face. This will help raise the level of understanding between parties and contribute to project success.

Customizing products, being fair in making and evaluating claims and writing down the objectives of different parties may lead to higher client satisfaction. The implication for sellers is that they should share information with owners or consultants, and be flexible when unforeseen matters occur.

It is recommended that sellers and buyers adopt the goal alignment practices identified in this study in order to improve project outcomes. These practices relate to strategies such as having shared goals, effective communication, flexibility, and fairness.

\section{References}

Aibinu, A.A., Ling, Y.Y. and Ofori, G. (2011) 'Structural equation modelling of organizational justice and cooperative behaviour in the construction project claims process: contractors' perspectives', Construction Management and Economics, 29 (5), 463-481.

Aibinu, A.A., Ofori, G. and Ling, Y.Y. (2008) 'Explaining cooperative behavior in building and civil engineering projects' claims process', Journal of Construction Engineering and Management, 134 (9), 681-691.

Ali, A., Don, Z., Alias, A., Kamaruzzaman, S. and Pitt, M. (2010) 'The performance of construction partnering projects in Malaysia', International Journal of Physical Sciences, 5 (4), 327-333.

Black, C., Akintoye, A. and Fitzgerald, E. (2000) 'An analysis of success factors and benefits of partnering in construction', International Journal of Project Management, 18 (6), 423-434.

Bubshait, A. and Almohawis, S. (1994) 'Evaluating the general conditions of a construction contract', International Journal of Project Management, 12 (3), 133-136.

Buckley, P.J. and Casson, M. (1998) 'A theory of cooperation in international business', in Beamish, P.W. (ed.) Strategic Alliances, pp. 91-110, Edward Elgar Publishing, Cheltenham, Glos and Northampton, Mass.

Business Monitor International (2012) Vietnam Infrastructure Report Q1 2013. Retrieved January 2013 from http://www.marketresearch.com/Business-Monitor-Internationalv304/Vietnam-Infrastructure-Q1-7226581/

Chan, E.H.W. and Chan, A.T.S. (2000) 'Imposing the ISO 9000 quality assurance system on statutory agents in Hong Kong', Journal of Construction Engineering and Management, 125 (4), 285-91.

Chan, A., Chan, D., Chiang, Y., Tang, B., E.H.W. and Ho, K. (2004) 'Exploring critical success factors for partnering in construction projects', Journal of Construction Engineering and Management, 130 (2), 188-198.

Chan, D., Chan, A., Lam, P. and Wong, J. (2011) 'An empirical survey of the motives and benefits of adopting guaranteed maximum price and target cost contracts in construction',

Ling, F Y Y and Hien, M B T (2014) 'Boosting project outcomes through goal alignment: a case study of Vietnam', Australasian Journal of Construction Economics and Building, 14 (2) 73-86 
International Journal of Project Management, 29 (5), 577-590.

Chartered Institute of Building (2010) Code of Practice for Project Management for Construction and Development, 4th ed., Blackwell, Oxford.

Cheng, E., Li, H. and Love, P. (2000) 'Establishment of critical success factors for construction partnering', Journal of Management in Engineering, 16 (2), 84-92.

Child, J. (1984) Organizations, Harper \& Row, London.

Dainty, A., Moore, D. and Murray, M. (2006) Communication in Construction: Theory and Practice, 1st ed., Taylor \& Francis, New York.

Dapice, D.O. (2003) Vietnam's Economy: Success Story or Weird Dualism? A SWOT Analysis, Harvard University, Cambridge, MA.

Dunston, P. and Reed, A. (2000) 'Benefits of small projects team initiative', Journal of Construction Engineering and Management, 126 (1), 22-28.

Eisenhardt, K.M. (1989) 'Agency theory: an assessment and review', Academy of Management Review, 14 (1), 57-74.

Global Finance (2012) Vietnam Country Report. Retrieved January 2013 from http://www.gfmag.com/gdp-data-country-reports/146-vietnam-gdp-country-report.html axzz2HCh6qsT

Gray, C. and Suchocki, M. V. (1996) 'Rapid team integration to overcome the construction industry's fragmentation', Proceedings CIB W65 International Symposium for the Organisation and Management of Construction - Shaping Theory and Practice (ed. D. A. Langford and A. Retik), vol. 2, pp. 627-639, E \& FN Spon, London.

Hellard, R. (1996) 'The partnering philosophy - a procurement strategy for satisfaction through a team work solution to project quality', Journal of Construction Procurement, 2 (1), 41-55.

Hermalin, B.E. (2001) 'Economics and corporate culture', in S. Cartwright, C. L. Cooper, and P. C. Earley (Eds.), Handbook of Organizational Culture and Climate, pp.217-261, Wiley, New York.

Hoai, L., Lee, D. and Lee, Y. (2008) 'Delay and cost overruns in Vietnam large construction projects: a comparison with other selected countries', KSCE Journal of Civil Engineering, 12 (6), 367-377.

Jap, S.D. (1999) 'Pie-expansion efforts: collaboration processes in buyer-supplier relationships', Journal of Marketing Research, 36 (4), 461-475.

Kaliba, C., Muya, M. and Mumba, K. (2009) 'Cost escalation and schedule delays in road construction projects in Zambia', International Journal of Project Management, 27 (5), 522531.

Kawneer (2001) Partnering. Kawneer Limited, Cheshire. Retrieved January 2013 from http://www.kawneer.com/kawneer/united kingdom/en/pdf/Partnering.pdf

Kim, J.Y., Kang, C.W. and Hwang, I.K. (2012) 'A practical approach to project scheduling: considering the potential quality loss cost in the time-cost tradeoff problem', International Journal of Project Management, 30 (2), 264-272.

Konchar, M and Sanvido, V. (1998) 'Comparison of US project delivery systems', Journal of Construction Engineering and Management, 124 (6), 435-444.

Lansley, P. R., Sadler, P., Webb, T. (1974) 'Organizational structure, management style and company performance', OMEGA, The International Journal of Management Science, 2 (4), 467-485.

Larson, E. (1995) 'Project partnering: results of study of 280 construction projects', Journal of Management in Engineering, 11 (2), 30-35.

Ling, F Y Y and Hien, M B T (2014) 'Boosting project outcomes through goal alignment: a case study of Vietnam', Australasian Journal of Construction Economics and Building, 14 (2) 73-86 
Lim, T.H.B., Ling, Y.Y., Ibbs, C.W., Raphael, B. and Ofori, G. (2011) 'Empirical analysis of the determinants of organizational flexibility in construction business', Journal of Construction Engineering and Management, 137 (3), 225-237.

Ling, Y.Y., Chan, S.L., Chong, E. and Ee, L.P. (2004) 'Predicting performance of DB and DBB projects', Journal of Construction Engineering and Management, 130 (1), 75-83.

Ling, F.Y.Y. and Bui, T. (2010) 'Factors affecting construction project outcomes: case study of VietGra', Journal of Professional Issues in Engineering Education and Practice, 136 (3), 148-155.

Ling, F.Y.Y. and Tan, P.C. (2014) 'Case study of implementation of relational norms in the construction of a public hospital', Proceedings $18^{\text {th }}$ PAQS Congress (ed. P. Ho), pp. 199-205, PAQS \& HKIS, Hong Kong.

Ling, F.Y.Y. and Tran, H.N. (2012a) 'Undesirable project management practices adopted to achieve project outcomes: a case study of Vietnam', International Journal of Project Organisation and Management, 4 (2), 153-170.

Ling, F.Y.Y. and Tran, T. (2012b) 'Ingredients to engender trust in construction project teams in Vietnam', Construction Innovation, 12 (1), 43-61.

Ling, F.Y.Y. and Tran, Q. (2012c) 'Effects of interpersonal relations on public sector construction contracts in Vietnam', Construction Management and Economics, 30 (12), 1087-1101.

Ling, F.Y.Y. and Tan, P.C. (2014) 'Case study of implementation of relational norms in the construction of a public hospital', Proceeding of the $18^{\text {th }}$ PAQS Congress 2014, ed. P. Ho, 199-205, PAQS \& HKIS, Hong Kong SAR.

Luu, T.V., Kim, S.Y., Cao, H.L. and Park, Y.M. (2008), 'Performance measurement of construction firms in developing countries', Construction Management and Economics, 26, 373-86.

Mejabi, O.O. and Singh, N. (1997) 'A framework for enterprise-wide integration', International Journal of Computer Integrated Manufacturing, 10 (1-4), 212-220.

Meng, X. (2012) 'The effect of relationship management on project performance in construction', International Journal of Project Management, 30 (2), 188-198.

Munns, A. (1995) 'Potential influence of trust on the successful completion of a project'. International Journal of Project Management, 13 (1), 19-24.

Nation Encyclopedia (2012) Vietnam. Retrieved January 2012 from http://www.nationsencyclopedia.com/economies/Asia-and-the-Pacific/Vietnam.html

Nguyen, L., Ogunlana, S., Truong, Q. and Lam, C. (2004) 'Large construction projects in developing countries: a case study from Vietnam', International Journal of Project Management, 22 (7), 553-561.

Nolo (2013) The Benefits of a Written Agreement, Nolo, Berkeley. Retrieved January 2013 from http://www.nolo.com/legal-encyclopedia/free-books/sharing-book/chapter5-2.html

Ott, R. and Longnecker, M. (2001) An Introduction to Statistical Methods and Data Analysis, Duxbury, Pacific Grove, CA.

Pinto, J., Slevin, D. and English, B. (2009) 'Trust in projects: an empirical assessment of owner/contractor relationships', International Journal of Project Management, 27 (6), 638648.

Project Management Institute (PMI, 2004). A Guide to the Project Management Body of Knowledge (PMBOK guide), 3rd ed., Project Management Institute, Newtown Square, PA.

Sorensen, J.B. (2002) 'The strength of corporate culture and the reliability of firm performance', Administrative Science Quarterly, 47, 70-91. 
Stephen, A.T. and Coote, L.V. (2007) 'Interfirm behavior and goal alignment in relational exchanges', Journal of Business Research, 60 (4), 285-295.

Swan, W. and Khalfan, M. (2007) 'Mutual objective setting for partnering projects in the public sector', Engineering, Construction and Architectural Management, 14 (2), 119-130.

Thomas, G. and Thomas, M. (2005) Construction Partnering and Integrated Teamworking, Blackwell, Oxford.

Thompson, P. and Sanders, S. (1998) 'Partnering continuum', Journal of Management in Engineering, 14 (5), 73-78.

Vaaland, T. (2004) 'Improving project collaboration: start with the conflicts', International Journal of Project Management, 22 (6), 447-454.

Van de Ven, A., Polley, D. E., Garud, R. and Venkataraman, S. (1999) Innovation Journey, Oxford University Press, New York.

Verma, V.K. (1998) 'Conflict management', in J. Pinto (Ed.), The Project Management Institute: Project Management Handbook, pp.353-364, Jossey-Bass, San Francisco.

Walker, D., Hampson, K. and Peters, R. (2002) 'Project alliancing vs project partnering: a case study of the Australian National Museum Project', Supply Chain Management, 7 (2), 83-91.

World Bank (2009) Rethinking Forest Partnerships and Benefit Sharing, The World Bank, Washington DC. Retrieved January 2012 from http://www.profor.info/sites/profor.info/files/Benefit Sharing WEB.pdf

World Bank (2012) Vietnam Development Report. Paper presented at the meeting of Vietnam Consultative Group in Hanoi, Vietnam, on 6 December 2011.

Wright, P.M., Dunford, B.B. and Snell, S.A. (2001) 'Human resources and the resource based view of the firm,' Journal of Management, 27 (6), 701-721.

Zaghloul, R. and Hartman, F. (2003) 'Construction contracts: the cost of mistrust', International Journal of Project Management, 21 (6), 419-424. 